University of Wollongong

Research Online

Faculty of Informatics - Papers (Archive)

Faculty of Engineering and Information

Sciences

$1-12-2006$

\title{
Historical lessons on ID technology and the consequences of an unchecked trajectory
}

Katina Michael

University of Wollongong, katina@uow.edu.au

M G. Michael

University of Wollongong, mgm@uow.edu.au

Follow this and additional works at: https://ro.uow.edu.au/infopapers

Part of the Physical Sciences and Mathematics Commons

\section{Recommended Citation}

Michael, Katina and Michael, M G.: Historical lessons on ID technology and the consequences of an unchecked trajectory 2006.

https://ro.uow.edu.au/infopapers/389

Research Online is the open access institutional repository for the University of Wollongong. For further information contact the UOW Library: research-pubs@uow.edu.au 


\title{
Historical lessons on ID technology and the consequences of an unchecked trajectory
}

\begin{abstract}
This paper traces the use of identification techniques throughout the ages and focuses on the growing importance of citizen identification by governments. The paper uses a historical approach beginning with manual techniques such as tattoos, through to more recent automatic identification (auto-ID) techniques such as smart cards and biometrics. The findings indicate that identification techniques born for one purpose have gradually found their way into alternate applications, and in some instances have been misused altogether. There is also strong evidence to suggest that governments are moving away from localized identification schemes to more global systems based on universal lifetime identifiers.
\end{abstract}

\section{Keywords}

national identification, automatic identification, smart card, biometrics, history, government

\section{Disciplines}

Physical Sciences and Mathematics

\section{Publication Details}

This article was originally published as: Michael, K \& Michael, MG, Historical lessons on ID technology and the consequences of an unchecked trajectory, Prometheus, 2006, 24(4), 365-377. The journal is available here from Taylor \& Francis journals. 
Historical lessons on ID technology and the consequences of an unchecked trajectory Katina Michael, M.G. Michael

School of Information Technology and Computer Science, University of Wollongong, New South Wales, Australia

\section{Abstract}

This paper traces the use of identification techniques throughout the ages and focuses on the growing importance of citizen identification by governments. The paper uses a historical approach beginning with manual techniques such as tattoos, through to more recent automatic identification (auto-ID) techniques such as smart cards and biometrics. The findings indicate that identification techniques born for one purpose have gradually found their way into alternate applications, and in some instances have been misused altogether. There is also strong evidence to suggest that governments are moving away from localized identification schemes to more global systems based on universal lifetime identifiers.

Keywords: national identification; automatic identification; smart card; biometrics; history; government

\section{$1 \quad$ Introduction}

This paper takes the reader through a historical tour of identification techniques from ancient times to today. The histories shed light on how the purpose of citizen identification has changed. The primary objective of the paper is to provide a thorough exploration of past and present government-related citizen ID schemes so as to better understand the possible uses (or misuses) of current and future mandatory 
ID. The paper also presents some of the evolutionary changes that have taken place in the nature and scope of citizen ID, and their subsequent potential implications on society. Historically governments have requested the registering of their population for census collection and more recently the need to know what social benefits accrue to each household but today citizen ID schemes are even used to open bank accounts. In addition, auto-ID techniques are not only pervasive but are increasingly becoming invasive. The significance of this paper is in its capacity to draw examples from history and to emphasize the types of issues that should be carefully deliberated in the introduction of any new national ID-based scheme. These schemes need forward planning and safeguards beyond those currently provided.

\section{Defining identification}

Identification is defined as "the act of identifying, the state of being identified [or] something that identifies one" [1]. The verb identify is linked to the noun identity, such as in the case of the term identity card which can be used to identify someone belonging to a particular group. Founded in Europe the word identity became noticeable in the English-speaking world around 1915 through Freud. The preferred definition for identity within the context of this paper is the "condition, character, or distinguishing features of person or things effective as a means of identification" [1].

\section{Early identification techniques}

Before the introduction of computer technology the various means of external identification were greatly limited. The most commonly used method was relying on one's memory to identify the distinguishing features and characteristics of other humans, such as their outward appearance or the sound of their voice. However, 
relying solely on one's memory had many pitfalls and thus other methods of identification were introduced. These included marks, stamps, brands, cuts or imprints engraved directly onto the skin, which were to be later collectively referred to as tattooing. A tattoo is defined as “...permanent marks or designs made on the body by the introduction of pigment through ruptures in the skin..." [2] Tattooing is considered by some to be the human's first form of expression in written form. "All the nomadic peoples try to distinguish themselves from the rest, to make themselves unique and also to establish a means of recognizing their kinsmen in the various clans. In order to achieve this, they resort to the resource which is the most accessible and the most lasting: their skin. This decorated skin defines the boundary against the hostility of the outside world, for it is visible to everyone and it accompanies the individual everywhere" [3].

Historical records date the first tattoo about 2000BC to Ancient Egypt, though there is evidence to suggest that tattooing was introduced by the Egyptians as early as 4000BC [4]. Tattoos on humans were considered both disapprovingly, and in some instances which were not lacking, quite acceptable. In the Old Testament in the Book of Leviticus 19:28, God commands Moses: "You shall not make any cuttings in your flesh on account of the dead or tattoo any marks upon you". Similarly in the New Testament in the Book of Revelation 13:16-17, there is the infamous passage about the beast who forces everyone "...both small and great, rich and poor, free and slave, to receive a mark on their right hand or on their foreheads, and that no one may buy or sell except one who has the mark..." [5] In classical literature however, tattooing served to identify the bearer's rank, status or membership in a group or profession. The historian, Herodotus (c. 484 BC - c. 425 BC) writes concerning the Thracians, 
"[t]hey consider branding a mark of high birth, the lack of it a mark of low birth" [6]. The mark was usually visible for others to recognize.

\subsection{The misuse of manual identification techniques}

Branding as a method of identification (especially of minority groups) continued throughout history. As far back as antiquity tattooing was generally held in disrepute, "[t]he ancient Greeks branded their slaves (doulos) with a delta, and the Romans stamped the foreheads of gladiators, convicted criminals sentenced to the arena, for easy identification" [4]. According to Paoli, “...the Romans fastened to the necks of slaves who were liable to run away an iron collar with a disc (bulla) firmly attached to it bearing the owner's name and address" [7]. Even until 1852, the French penal system would identify thieves by "...a V tattooed on the right shoulder, and galley slaves by the three letters GAL" [3]. United States convicts and British Army deserters were similarly treated.

In recent times however, society has become intolerant of tattooing as a means of enforced segregation where the act is committed without the permission of the bearer, with dubious intent. Nazi dictator Adolf Hitler in his planned genocide of the Jewish people during World War II (1939-1945) enforced various methods of identification to separate them from the rest of the population. There is even evidence to suggest that punch cards originally intended to help in the tabulation of census data, were used instead to help segregate the Jewish people from the rest of the German and Polish populations [8]. On September of 1941, an order was issued that all Jews were to wear a Star of David badge [9]. Those who did not comply with such orders were sent to Nazi extermination camps immediately where they were “...branded like animals. A registration number, corresponding to the camp, was stamped on the left forearm. 
This was preceded with a "D" if the person was Jewish..." [3] In the Drowned and the Saved, Primo Levi, an Auschwitz survivor, writes of the mandatory tattooing of individuals that occurred in the concentration camp: “...a true and proper code soon began to take shape: men were tattooed on the outside of the arm and women on the inside; the numbers of the Zigeuner, the gypsies, had to be preceded by a Z. The number of a Jew, starting in May $1944 \ldots$ had to be preceded by an A, which shortly after was replaced by a B... After this date, [September 1944] there began to arrive entire families of Poles... all of them were tattooed, including newborn babies" [10]. In this case both the character and the number were used for identification. The character indicated the group the individual was linked to and the number uniquely identified the individual. Another survivor was quoted in The Nazi Doctors: medical killing and the psychology of genocide, "I remember when... that thing [the number tattooed on each prisoner's forearm] was put on..." [11] That thing according to another account stood for dehumanization. "And as they gave me my tattoo number, B-4990, the SS man came to me, and he says to me,l "Do you know what this number's all about?”| I said, "No, sir.”| “Okay, let me tell you now. You are being dehumanized" [12]. Even until the fall of communism, the former Soviet Union used branding methods on exiled criminals and political prisoners in Siberia, for security purposes [13].

Of course the wearing of a badge does not immediately imply misuse- it all depends on the context and who it is that has requested this manner of identification and for what purpose. For instance, European migrants in the early 1900s travelling by ship to New York City were given a badge to wear to make identification easier while going through immigration. The badge was either pinned on clothing or as in the majority of cases tied to a cotton necklace. After undergoing a medical examination certain letters 
would be recorded on the badge to identify the condition of the immigrant, especially if further screening was required. Those suspected of suffering from mental illness or other health concerns not acceptable to authorities were separated from larger groups and sent back to their homeland. There was simply no other manner in which hundreds of thousands of people could be processed efficiently in such a short period. The badge also alleviated the requirement for the migrant to communicate with officials, especially because the majority did not know English and this would have been a cumbersome process.

One can see that the early identification techniques, while primitive in nature, could be hideously misused against minority groups in helpless situations. Plainly, when a technique becomes available it is applied wherever it is required, "without distinction of good or evil" by whomever has the capability and authority [14]. Ellul believed that the technique itself has an autonomous mandate, that “...once man has given technique its entry into society, there can be no curbing of its gathering influence, no possible way of forcing it to relinquish its power. Man can only witness and serve as the ironic beneficiary-victim of its power" [15]. That being true, advances in data collection techniques have even greater far-reaching effects.

\section{$4 \quad$ Advances in record-keeping}

As manual record-keeping procedures evolved, identification became an integral part of the data collection process. Widespread branding of people was unacceptable and thus other means had to be developed to allow authorities to keep track of individuals. These means varied throughout the ages but increased in sophistication especially after the Industrial Revolution. When automation occurred most of the manual techniques were ported into an electronic environment. The following section is 
meant to shed light on some of the incremental innovations that led to the development of automatic identification.

\subsection{The registering of people and the census}

The registering of people dates back to ancient times. "Now go throughout all the tribes of Israel, from Dan to Beersheba, and count the people, that I may know the number of the people" (2 Samuel 24:2; rf 1 Chronicles 21:1,7; Esther 6:1). And the Romans were particularly advanced in their data collection requirements, wishing not only to count but to gather additional information about their citizens: "A periodic census of Roman citizens was held... every four years, but from 209 BC onwards... every five years... This was a reflection of the mustering of the army into centuries, and it was these men, grouped in the five classes, that were the chief concern of the censors who had to register them in their tribes and assess their property in order to assign them to the correct classes for purposes of both taxation and military services. The head of each family had to answer questions about the property and age of all its members..." [16] Consider also Luke 2:1-3: "And it came to pass in those days that a decree went out from Caesar Augustus that all the world should be registered. This census first took place while Quirinius was governing Syria. So all went to be registered, everyone to his own city."

Censors had to rely on manual identification techniques to ensure the accuracy of inventories. This was a very difficult and time-consuming task, especially since “...houses had no numbers, and many streets were nameless. The ancients had not discovered the countless practical advantages of numbers" [7]. An error made by the censor could impact the life of a citizen since "early inventories were made to control particular individuals- for example, to identify who should be taxed, inducted into 
military service, or forced to work" [17]. Over time however, newer more advanced techniques were developed which ultimately served to change the purpose of the population census. However, it should be noted, that "[s]trictly speaking, the modern population census began in the 17th century. Before then, inventories of people, taxpayers, or valuables were made; but the methods and purposes were different to modern ones" [17]. More automated means of identification and data collection made it possible for census surveys to be extended. For example, in the U.S. Census of 1890, part of the process of classifying and counting the data collected was automated. Herman Hollerith invented a method that allowed census takers to punch holes in predetermined locations to represent various characteristics. The holes were then processed by a machine. As elementary as this may seem, such advances led to subsequent breakthroughs in the field [18]. Of course, this does not mean that errors in the data collection of personal information are no longer incurred.

\subsection{Record-keeping by the Church and State}

The overall intent of a census was to determine the aggregate profile of people residing within a defined geographic region so that authorities could address their needs appropriately. "Census statistics are used as the basis for estimating the population at the national, state and local government levels, for electoral purposes and the distribution of government funds. They are used by individuals and organizations, in the public and private sectors, for planning, administration, research, and decision making" [19]. However with advances in social welfare, authorities required to know more specific details about their citizens and their individual circumstances. In establishing an official relationship with the citizen, identification and specialized record-keeping practices became important from the perspective of 
the state. A variety of paper-based documentation was instituted; in some cases special seals or ink-based stamps were used to indicate legality. Examples of official documentation included land title deeds, birth certificates and bank account records. These were among the most common proofs of identity but this varied dependent on the state in question and period of history. The importance of the church in the evolution of record-keeping should also be highlighted. In many parts of the world the local church was a thorough documenter of events and very much an integral part of government until about the Middle Ages. The church and state had their own law and court systems and there were often issues over jurisdictional rights [20,21]. The interaction of the church and state led to developments in the centralization of government and bureaucracy. With the centralization of power came a need for the centralization of citizen information which led to the creation of personal files. Churches also provided proofs of identity, such as marriage and baptismal certificates. Some churches even kept records of disputes or wrong-doings and how victims had been recompensed. Given that the size of towns was relatively small compared to today, names could be used to identify individuals. Given names and surnames were not always unique. In some instances the name was accompanied by the paternal lineage, or an address location, or by a nickname. However even address locations in ancient times were for the greater part difficult to precisely identify. In ancient Rome, roads were nameless "and were referred to simply by such expressions as 'The road to...'; a few of the more important had names" [7]. But the Industrial Revolution was set to change things dramatically, especially as mass production drew large groups of people (in most cases from surrounding towns) closer towards employment opportunities in factories. 


\subsection{The notion of a personal document file}

One of the earliest modern day responses to improved identification techniques and record-keeping standards came in 1829. In that year, British Parliament made a decision to enact the reforms of Prime Minister Robert Peel who wanted more emphasis to be placed on printed police records. In this manner relevant data could be stored in a personal document file and linked back to individuals using a unique value. In many ways these records were forerunners to government databases that were linked to ID cards. During this same period, photographic technology was invented but it was not until 1840 that amateur scientist William Henry Fox Talbot developed the negative-positive photographic system which eventually became a useful police identification tool. In an age of computers, humans generally take for granted the invention of the still-shot camera and motion camera because the technology is so readily available. But a simple ID badge with a photograph on it really did not become widespread until after the Second World War. Photographs fastened to cards were excellent manual identifiers, before the proliferation of cameras which then enabled fake IDs to be developed by criminals. As soon as this occurred an additional measure was required to ensure positive identification. In the meantime, signatures were the most reliable unique method of cross-checking someone's identity between original and duplicate copies. This was all dependent on the literacy level of the individual, though unique markings were accepted as substitutes. By the late 1870s, a significant breakthrough in identification came about in India. Sir William Herschel (a British 'Magistrate and Collector') had made a defendant's fingerprint part of court records. Ron Benrey reported that Herschel used fingerprints as manual signatures on wills and deeds [22]. For the first time, a biometric had officially become a means of precise identification. In 1901, police 
technology had advanced so much that Scotland Yard had introduced the GaltonHenry system of fingerprint classification. Till today, fingerprints have been associated with crime for this reason. The system did not become widespread because the practicality of taking fingerprints of all citizens and cross-matching records for individual transactions was not viable at the time.

\subsection{The evolution of the citizen ID number}

Unique citizen identification numbers were adopted by numerous countries around the period of the Great Depression. Unique identifiers in the context of citizen numbers are known by a variety of names. These include: identification number (IN), personal identification number (PIN), uniform personal identification mark (UPIM), national identification number (NIN), universal identification number (UIN), unique identification system (UIS), universal identifiers (UID), unique personal identifier (UPI), single identifying number (SIN), standard universal identifier (SUI), universal multipurpose identifier (UMI), universal personal number (UPN), unique lifetime identifier (ULI). The majority of these nation-wide numbering schemes have been maintained, relatively unchanged, till today. Some of the national numbering schemes include: the Person Number (PN) system of Norway, the Central Register of Persons (CRP) in Denmark, the German Insurance Number (GIN), the Social Account Number (SAN) of Austria, the Insurance Number (IN) of the former Czechoslovakia, the French Identification Number (FIN), the Insured Persons Number (IPN) of Switzerland and the National Insurance Number (NIN) of the United Kingdom [23]. The initial person registration system used in Sweden dates back about three hundred years when the process involved the Church of Sweden. Local parishes were considered to be like regional administration offices. But in 1947 each person was 
assigned a PN that was recorded electronically in 1967 from metal plates to magnetic tape. The Netherlands used the census of 1849 as a starting point for there decentralized PN system. But in 1940 personal cards with unique numbers were issued to the whole population that acted as lifetime identifiers. In Israel a PN was allotted in 1948 via a census after the State of Israel was officially established. A Population Registry Law in 1965 established the basic information that had to be collected when registering. This involved disclosing details about the ethnic group that one belonged to, as well as religious beliefs and past and present nationalities. In 1966, this information was computerized. Iceland has used a population register since 1953. When a citizen reaches the age of twelve they are given a number that is based on the alphabetical sequence of a person's name in the total population. In 1964, Norway's Central Bureau of Statistics was asked to establish a national identification numbering system as the world learnt of the potential of electronic data processing (EDP). In 1968, Denmark followed in Norway's footsteps by computerizing their records as well. France has used numbering systems for individuals and organizations since 1941. The system was computerized in 1973 after existing records were put on magnetic tape and adapted to include check digits. Finland introduced their personal identification code (PIC) system in 1964 [24]. The potential for a globally implemented unique national identifier (UNI) is realistic. This could be tied in with the concept of a follow-me telephone number. For the purpose of showing the evolution of the citizen ID number, one of the oldest schemes, the United States social security number ( $\mathrm{SSN}$ ), will be discussed in more detail. The maturation of the SSN is representative of many person number schemes worldwide.

5 The U.S. Social Security Administration (SSA) 
By the 1920s, countries like Britain, Germany and France were using personal document files to administer specific government assistance schemes for unemployment, worker's compensation, health, pensions and child endowment [25]. Western European countries had established population registers that were updated continually to include the name, residence, age, sex and marital status of an individual. The registers were administered at a municipal or county level initially but towards the mid-1900s they became more centralized. There was an increasing demand for the registers by government for voting, education, welfare, police and the courts. In observing the processes of the European governments, the United States (U.S.) sought even more efficient methods of identification. Thus the Social Security Administration (SSA) was formed, a centrally managed scheme, supported by an official Act in 1935. Setting up the program was a daunting task. The U.S. government was dealing with a large group of people (five million elderly people alone), each personal record attached to several applications (pension, medicare, family allowance etc.), and individuals were geographically dispersed. Since money and benefits were being distributed at a cost to taxpayers, the government was obligated to establish guidelines as to eligibility, proof of identity and citizenship to keep track of funds [26].

\subsection{The SSN gathers momentum - more than a number}

As government policies became more sophisticated, administrators required a mechanism for the unique identification of individuals to improve the efficiency of operations. In 1938 the social security number (SSN) was introduced. The SSN was phased in to reduce the incidence of duplicate records, allow for more accurate updates and ensure that entitlements were received by the bona fide. With the 
introduction of the SSN came the social security card. Each card contained the nine digit SSN and the cardholder's name. The card (with the printed number on it) was useful in that cardholders could carry it with them and quote it freely when requested to fill out government forms. It meant that citizens did not have to memorize the number or risk referencing it incorrectly. The card also acted as a proof of identity. This deterred many people from making fraudulent claims, yet the quality of the paper card was poor and susceptible to damage. Thus the need for cards to be made out of more durable material ensued. Cards made out of cardboard were initially introduced, followed by plastic cards with embossing. By 1943, President Roosevelt had signed “...Executive Order 9397 (EO9397) which required federal agencies to use the number [SSN] when creating new record-keeping systems" [27]. In the early fifties the insurance and banking sector also adopted the SSN and requested it from each individual who wanted to open a bank account and make monetary transactions. By 1961, the Internal Revenue Service (IRS) was also using the SSN as a taxpayer identification number (TIN). It can be seen that knowledge gained from the improved administration of government services was applied to other sectors, such as finance. Thus the ID number itself, had two important uses when the computer age arrived. First it could be used as a primary key for storing personal information in databases. Second it could be linked with any identification technique for authentication or verification. It was the ID itself that was fundamental to these applications whether in the form of a unique number, character set, symbol or image. The ID device accompanying the ID was more a facilitator. What should be observed is that even without advanced hardware equipment and automatic identification techniques, the underlying information systems concept had been born. 


\subsection{The computerization of records}

The proportion of recorded transactions was now reaching new limits in the United States. Written records had served their purpose but could no longer effectively support the collection, storage and processing of data. Government agencies were plagued by such problems as limited physical storage space for paper documentation; slow response times to personal inquiries; inaccurate information stored in personal records; difficulties in making updates to records; duplicate information existing for a single person; and illegal and fraudulent claims for benefits by persons. By 1970 the SSA had set up its headquarters in Baltimore. The basic data stored there included the “...social security status of every citizen with a social security registration... and equivalent records on all phases of the Medicare program." The SSA had established 725 field offices and citizen transactions were communicated to headquarters via dedicated circuits where it was received on magnetic tape ready for input into the SSA computer [28]. Initially, the types of analysis that could be performed on records were limited [29]. By 1977 however, the government had not only computerized its paper records but had even developed computer matching applications. The Public Law 95216 "mandated that state welfare agencies use stage wage information in determining eligibility for Aid to Families with Dependent Children (ADFC). Subsequent legislation also required similar wage matching for the Food stamp program” [30]. By the early 1980s it was common for data matching programs to check personal records between social security, other federal agencies and the banking sector. In this manner the government could determine whether a citizen was receiving legitimate funds and contributing to the nations numerous taxes. Thus, the emergence of the microprocessor and the development of electronic storage devices enabled the invention of information technologies that could automate the process of identifying 
living and non-living things [31]. Historically auto-ID systems have been constrained by the capabilities of other technologies they have been dependent upon. Limitations in network infrastructure, central processing unit (CPU) speeds, electronic storage space, microchip miniaturization, and application software and data collection devices are just some of the components that have impacted auto-ID.

\subsection{Problems with some government citizen identifiers}

The U.S. social security number ultimately became a multi-purpose identifier though originally it was only meant to be used for social security purposes. As paper records were transferred into a machine-readable format and simple searches performed it became apparent that there were duplicate SSNs. One must note that the SSN was created without the knowledge of how computer technology would revolutionize the government's processes. By the time computers and networks were introduced into the SSA's practices, the SSN was a legacy system that maintained numerous embedded problems. The main cause for concern arose because the identifier's composition was never well-defined; neither was it randomly or sequentially generated. The nine digit SSN was broken up into three sections: area number assigned to states on a population basis, group number (2 digits), and serial number assigned sequentially (4 digits) which was controlled by the first six letters of the person's surname [23]. When the regional-based ID numbers were pooled together to form a central population register (CPR) the IDs were found not to be unique. As Hibbert critically points out, "[m]any people assume that Social Security numbers are unique, but the SSA didn't take sufficient precautions to ensure that it would be so" [27]. In addition to this, the SSA itself was forced to admit that more than four million people had two or more SSNs [32]. This immediately posed a problem for both 
authorities and citizens. The computer system could not handle cases adequately whereby there were more than 999 persons with a surname beginning with the exact same 6 letters living in the same area (as defined by the SSA). While this may sound impossible to achieve some names are very common and a lot of surnames are shorter than 6 characters in length. In other cases the problems that some citizens have endured after their SSN has been stolen, have been well-documented and receive plenty of attention from popular media.

\section{Post Sept 11- the changing face of ID}

In the United States, after the terrorist attacks of Sept 11in 2001, several bills were passed in Congress to allow for the creation of three new Acts related to biometric identification of citizens and aliens- the Patriot Act, Aviation and Transport Security Act, and the Enhanced Border Security and Visa Entry Reform Act. Many civil libertarians were astounded at the pace at which these bills were passed and related legislation was created. The USA has even placed pressure on international travellers and their respective countries to comply with biometric passports or forgo visiting altogether. To some degree national security measures are moving from a predominantly "internalized" perspective to an outward-looking view. With this change has been a re-shaping of nation-specific requirements for citizens both incountry and outside its borders to comply with obligatory conditions. For example, in 2002 Britain announced plans to chip implant illegal immigrants to control migration, and in 2003 Singapore seriously considered electronic tagging for persons suspected of carrying the deadly Severe Acute Respiratory Syndrome (SARS). Heightened national security sensitivities have meant a reorganization of our priorities and values, especially when it has come to identification. It seems we have now 
become obsessed with identifying as a means to providing additional security, as if this is the answer to national security. This is not to say that clear advantages do not exist in the use of automated systems. For example, in 2004, unidentified Tsunami victims who lost their lives in Thailand were actually fitted with RFID chips so that their loved ones might have been able to identify them later [33]. But by and large governments are now introducing sweeping changes to citizen ID systems without considering the probable repercussions into the future.

What started out as a need to identify individuals within one's borders has now evolved into a national-wide scheme and is poised to make a debut as an international-based solution. Blocks forming like the European Union with a single currency are potentially the first test-beds for the larger scale ID schemes. Livestock in EU countries for example are currently being identified uniquely based on a common standardized approach described in a legislative directive. The question to ask, however, is who can ensure that current and future schemes are not misused by any ruling individual or power base. While automatic identification schemes offer convenience, speed, higher productivity, better accuracy and efficiency, they are in their very nature "controlling” techniques- they either grant access or deny it. History has shown what was possible with largely manual-based techniques during WWII, auto-ID techniques at the disposal of a similar head of state could be manifold more intrusive. One need ask now, what safeguards have been put in place to prevent the misuse or abuse of one's personal ID? Some auto-ID technologies even pose legal dilemmas. One could claim that biometric techniques for instance, and beneath-theskin RFID transponders, do encroach on an individual's privacy when used for ID. Biometrics like fingerprints or DNA are wholly owned by the individual yet requested and stored by the state on large citizen databases. 
While in today's society the need for ID is unquestionable, we need to ensure we do not enforce changes that are irreversible and perhaps even uncontrollable. While national ID schemes were introduced by a number of countries after the Great Depression of the 1930s, what has changed since their inception are the technological capabilities that we have at our fingertips. These auto-ID technologies are manifold more powerful and when enjoined to other automated processes are a magnitude more invasive. The periodic census is a fine example of something that was introduced by the church and state to collect data in order to help provision services for citizens. Today, however, aggregated census data is being sold as a commodity to help private organizations perform more precise "target marketing". Perhaps it is not too long before our "private" IDs also undergo a similar transformation- "DNA for sale, anyone?"

\section{$7 \quad$ Numbers everywhere}

In his book, Rome: its people, life and customs, Ugo E. Paoli (1990, ch. XIII) emphasizes the significance of numbers by describing what it was like in ancient Roman times without street addresses. He contrasts this setting, i.e. the streets without names and the houses without numbers, by referring to how numbers are used profusely today in modern civilization. It is worth quoting Paoli at length:

"[w]hen we travel, our train has a number, as do the carriages, the compartments, the seats, the ticket-collector, the ticket and the note with which we buy our ticket. When we reach the station we take a taxi which is numbered and driven by a driver similarly numbered; on arrival at our hotel we become a number ourselves. Our profession, age, date of arrival and departure are all reckoned in numbers. When we have booked a room, we become a number, 42 perhaps, and if we are so unfortunate as to forget our 
number we seem to have forgotten ourselves. If we mistake it, we run the risk of being taken for a thief, or worse. The number is on the disc hanging from the key in our room; it is above the letter rack in the hall; every morning we find it chalked on the soles of our shoes, and we continually see it on the door of our room, and, finally, we find it on the bill. We grow so used to our number that it becomes part of us; if we have a parcel sent to the hotel, we give the number 42; however important we may be, to the porter and the chambermaid we are simply No. 42" [7].

Everything is indeed numbered. Even we ourselves are numbered. And as Paoli continues, this great ease in identifying everything is supposedly "a result of our position as modern civilized men" [7]. These ubiquitous ID numbers (which include addresses) follow us everywhere, and not unexpectedly as Paoli also reckons, have almost become a part of our personalities. On extending this notion Paoli reminds us that even if one finds themselves homeless, without an income, without any hope for the future, they still have their ID number. In a similar light what should be underscored is the increasing requirement today towards obligatory practices to do business with one's ID number(s). Whether making a transaction over the counter, through the mail, or on the telephone, service providers have become more interested in our customer reference number than our name. One is led to a justifiable conclusion of whether in amongst all these manufactured numbers we are little by little, losing our natural right to be called by our given name, and hence allowing for the defeat of our identity.

\section{Conclusion}

Tracing the path from manual identification through to automatic identification some conclusions may be drawn. First, the practice of identification has been sourced to 
very ancient times. Second, throughout history manual ID of humans was not always a voluntary modus operandi, especially in the enforced tattooing of individuals by some extreme groups. Third, the identification processes and procedures that were developed before automation were replicated after automation and dramatically enhanced because computer technology allowed for more powerful processing of information. Legacy systems however did impact automation. Fourth, the success of auto-ID was dependent on the rise of information technology. In many ways auto-ID was limited by a variety of hardware and software system components. As soon as these became feasible options for service providers, both in affordability and usability, auto-ID flourished. Fifth, the widespread adoption and acceptance of autoID by citizens is indicated in that people carry so many different ID devices for different applications. And finally, and most importantly, national ID schemes are becoming increasingly pervasive, complemented by highly invasive technologies. Governments need to be forward-thinking when they introduce new schemes and/or new devices, or extend existing schemes to new application areas, particularly of a commercial nature such as banking. No one can predict the future but one thing is certain, if a technology (high-tech or other) is open to misuse, it will eventually be abused.

\section{References}

[1] A. Delbridge et al. (eds), 'Identification', Macquarie Dictionary, Macquarie University, Sydney, 1998, p. 1062.

[2] Britannica, 'Tattoo', The New Encyclopaedia Britannica Micropaedia, Helen Hemingway Benton, Sydney, Vol. IX, 1983, p. 841. 
[3] C. Grognard, The Tattoo: Graffiti for the Soul, The Promotional Reprint

Company, Spain, 1994, pp. 19, 21, 25.

[4] T. Cohen, The Tattoo, Savvas, Sydney, 1994, pp. 25, 32.

[5] M. G. Michael, The Number of the Beast, 666 (Revelation 13:16-18): Background, Sources and Interpretation, MA (Hons) dissertation, Department of History,

Philosophy and Politics, Macquarie University, Sydney, 1998.

[6] Herodotus, The Histories, Penguin Books, London, 1972, p. 282.

[7] U. E. Paoli, Rome: its People, Life and Customs, Bristol Classical Press, London, 1990, pp. 138-140.

[8] E. Black, IBM and the Holocaust, Little, Brown and Company, U.K., 2001, pp.

$22,58$.

[9] M. Kitchen, Nazi Germany at War, Longman, Essex, 1995, p. 202.

[10] P. Levi, The Drowned and the Saved, trans. Raymond Rosenthal, Summit Books, London, 1998, p. 118f.

[11] R. J. Lifton, The Nazi Doctors: Medical Killing and the Psychology of Genocide, Basic Books, New York, 1986, p. 165.

[12] M. Dery, Escape Velocity: Cyberculture at the End of the Century, Hodder and Stoughton, London, 1996.

[13] C. P. Jones, 'Stigma: tattooing and branding in Graeco-Roman antiquity', The Journal of Roman Studies, 77, 1987, pp. 148-150.

[14] J. Ellul, The Technological Society, Vintage Books, New York, 1964, pp. 98-100.

[15] W. Kuhns, The Post-Industrial Prophets: Interpretations of Technology, Harper Colophon Books, New York, 1971, p. 94.

[16] H. H. Scullard, Festivals and Ceremonies of the Roman Republic, Thames and Hudson, London, 1981, pp. $232 \mathrm{f}$. 
[17] Britannica, 'Census', The New Encyclopaedia Britannica Micropaedia, Helen Hemingway Benton, Sydney, Vol. II, 1983, p. 679.

[18] G. D. Austrian, Herman Hollerith: Forgotten Giant of Information Processing, Columbia University Press, New York, 1982.

[19] I. Castles, CDATA91 Data Guide: 1991 Census of Population and Housing, Australian Bureau of Statistics, Canberra, 1993.

[20] C. T. Anglim, Religion and the Law: a Dictionary, ABC-CLIO, California, 1999.

[21] R. C. van Caenegem, The Birth of the English Common Law, Cambridge University Press, Cambridge, 1988.

[22] DSS, 'Understanding public perception', Connecticut Department of Social Services [Online], Available (1998, November 23)

http://www.dss.state.ct.us/faq/disuppt.htm

[23] NZCS, 'Investigation of a unique identification system', New Zealand Computer Society, May, 1972, pp. 28-29.

[24] A. S. Lunde et al., The Person-Number Systems of Sweden, Norway, Denmark, and Israel, U.S. Department of Health and Human Services, Maryland, 1980.

[25] C. Clark, 'The advance to social security', Realities of Reconstruction 9, Melbourne University Press, Carlton, 1943, p. 9.

[26] SSA, 'History: Social Security Online', [Online], Available (2003, March 30): http://www.ssa.gov/history/ brief.html

[27] C. Hibbert, 'What to do when they ask for your social security number', in R. Kling (ed.), Computerization and Controversy: value conflicts and social choices, Academic Press, New York, 1996, pp. 686-696.

[28] A. Miller, The Assault on Privacy: Computers, Databanks and Dossiers, New American Library, London, 1971, p. 77. 
[29] B-A. Lipetz, 'Information Storage and Retrieval' in Scientific American, W. H. Freeman, London, 1966, p. 191.

[30] R. P. Kusserow, 'The government needs computer matching to root out waste and fraud', in R. Kling (ed.), Computerization and Controversy: value conflicts and social choices, Academic Press, New York, part 6, section E, 1996, pp. 653f.

[31] D. B. Yoffie (ed.), Competing in the Age of Digital Convergence, Harvard Business School, Massachusetts, 1997, pp. 41-110.

[32] A. F. Westin and M. A. Baker, Databanks in a Free Society, Quadrangle Books, New York, 1972, pp. 396-400.

[33] J. Smith, 'Too many corpses to count', DailyRecord, [Online]. Available (2005, January 1): http://www.dailyrecord.co.uk 